Research Article

\title{
A comparative study of knowledge, attitude and practice of self-medication among medical and para medical students in a medical college, Mangaluru, Karnataka, India
}

\author{
Pooja Mapala $^{1 *}$, Rajendra Holla ${ }^{1}$, Swathi Acharya ${ }^{1}$, Tittu Zachariah $^{1}$, \\ Puneeth Aipanjiguly ${ }^{2}$
}

\begin{abstract}
${ }^{1}$ Department of Pharmacology, K.S. Hegde Medical Academy, Mangaluru, Karnataka, India

${ }^{2}$ Authorized laboratory signatory, Omega Hospitals, Mangaluru, Karnataka, India

Received: 08 March 2016

Accepted: 08 April 2016

*Correspondence to:

Dr. Pooja Mapala,

Email: rpoojam@gmail.com

Copyright: (C) the author(s), publisher and licensee Medip Academy. This is an openaccess article distributed under the terms of the Creative Commons Attribution NonCommercial License, which permits unrestricted noncommercial use, distribution, and reproduction in any medium, provided the original work is properly cited.
\end{abstract}

\begin{abstract}
Background: Self-medication is defined as use of medicines without a doctor's prescription and is frequently practiced among students in professional colleges. The purpose of this study was to compare the knowledge, attitude and practice of self-medication among second year medical and paramedical students in K. S Hegde Medical Academy, Mangaluru, Karnataka, India.

Methods: A prospective, observational, questionnaire based study conducted where two groups of students, Medical and Paramedical were interviewed with a prevalidated questionnaire. Demographic data and questions regarding knowledge, attitude and practice of self-medication were included. Details and purpose of the study was explained to the students. The collected data was analysed statistically and the comparison between the two groups was done.

Results: Total 247 students were involved in the study, group I consisting of 135 medical students and group II consisting of 112 paramedical students. All the students have practiced self-medication, however only $47.3 \%$ students agree with the practice. Accordingly, there are significant differences among the two groups in terms of reasons to choose self-medication and awareness about generic and brand names of drugs. Knowledge and practice about use of a particular drug for a particular condition was not balanced among the two groups.

Conclusions: Self-medication is a common form of health care with potential benefits and hazards. Hence, it is very important to increase the awareness about the advantages and disadvantages of self-medication in medical college students to improve their knowledge, attitudes and practices of self-medication and eventually to increase the awareness in the society.
\end{abstract}

Keywords: Self-medication, Questionnaire, Knowledge, Attitude, Practice

\section{INTRODUCTION}

Self-medication, an important component of self-care, is the most common practice in developing countries. It is defined as the use of drugs to treat self-diagnosed illnesses or irregular use of a prescribed drug for a chronic disease. ${ }^{1}$

Traditionally, self-medication is described as the use of drugs, herbs or home remedies on advice of another individual or one's own initiative without consulting a doctor. $^{2}$ WHO defines self-medication as, "use of medication by a patient on his own initiative or on the advice of a pharmacist, or a lay person, instead of consulting a medical practitioner., ${ }^{, 4}$

Various factors determining self-medication include: socioeconomic factors like growing empowerment, improved quality of education, health consciousness, advanced technology like internet and other communication systems, modern lifestyle, easy accessibility to the medicines, awareness about treatment of illnesses and rehabilitation, inappropriate nutrition. ${ }^{5}$

The practice of self-medication has brought the concept of over the counter drugs which are also called as non- 
prescription medicines. These drugs are available without doctor's prescription through pharmacies. ${ }^{6,7}$

Though self-medication forms a cornerstone for the health care system, it has potential benefits and health hazards. It may be beneficial at both individual level and community level. At individual level, it serves as an active role in his/her own health care, provides an opportunity of self-reliance in prevention or treatment of his/her symptoms along with providing financial benefits and convenience. At community level, it prevents wastage of medical resources, reduces absenteeism from work and pressure on medical services with insufficient health personnel. Potential hazards include: incorrect diagnosis and choice of therapy, lack of knowledge about certain pharmacological risks like drug-drug interactions, food and drug interactions, adverse effects, warnings and precautions, wrong dosage and route of administration, risk of drug dependence and abuse. ${ }^{8}$

Among the general population, self-medication is more commonly practiced in the youth. During the first year, the medical and paramedical students are equivalent to the general population with regards to their knowledge in self-medication. But over the time, after being exposed to the knowledge about drugs and diseases the attitude as well as the practice changes. Hence this study was planned to compare the knowledge, attitude and practice of self-medication among second year medical students and second year paramedical students in K.S. Hegde Medical Academy, Mangaluru, Karnataka, India.

\section{METHODS}

The study was initiated after obtaining approval from the institutional ethics committee. This was a prospective, observational, questionnaire based study where two groups of students were interviewed with a prevalidated questionnaire. The first group comprised of students from second year MBBS while the second group consisted of students of paramedical courses namely physiotherapy, operation theatre technicians and lab technicians. Details and purpose of the study was explained to the students clearly. Students not willing to participate in the study were excluded.

The questionnaire comprised of demographic data and 15 questions regarding the knowledge, attitude and practice of self-medication. Details regarding the knowledge about the drugs used in self-medication, generic and brand names, importance of completing course of treatment, package insert, source of information, common conditions for taking self-medication, commonly used medicines, side effects, advantages and disadvantages and the role of pharmacist in self-medication were emphasized in the questionnaire. The collected data was analysed statistically by using SPSS version 19 . Comparison between the two groups was done by using the Independent T-test.

\section{RESULTS}

A total of 247 students with an average age 19.3 \pm 0.87 years participated in the study. Among these students, 135 were medical students. All the students had practiced selfmedication however, only $47.3 \%$ agreed with the concept of self-medication. Considering the significant ' $p$ ' value to be $<0.05$ there was a significant difference among the 2 groups with respect to awareness of generic and brand names of the drugs and importance of completing the course of treatment. $48.9 \%$ of medical and $28.6 \%$ paramedical students were aware about generic and brand names of drugs ('p' value: 0.001 ) while knowledge about importance of completing course of treatment was present in $63 \%$ medical and $42.9 \%$ paramedical students. (' $p$ ' value: 0.002). Also, there was no significant difference regarding the knowledge about the content, dose, duration of treatment and frequency of drug administration among the two groups (Table 1).

\section{Table 1: Knowledge about content, dose, duration of} treatment and side effects.

\begin{tabular}{|llcl|}
\hline Knowledge & $\begin{array}{c}\text { Medical } \\
\mathbf{n ( \% )}\end{array}$ & $\begin{array}{c}\text { Paramedical } \\
\mathbf{n}(\%)\end{array}$ & $\begin{array}{c}\text { 'p' } \\
\text { value }\end{array}$ \\
\hline Content only & $44(32.6)$ & $45(40.2)$ & 0.26 \\
\hline Content, dose & $46(34.1)$ & $30(26.8)$ & 0.218 \\
\hline $\begin{array}{l}\text { Content, dose, } \\
\text { duration of } \\
\text { treatment }\end{array}$ & $22(16.3)$ & $27(24.1)$ & 0.126 \\
\hline $\begin{array}{l}\text { Content, dose, } \\
\text { duration, side } \\
\text { effects }\end{array}$ & $23(17)$ & $10(8.9)$ & 0.06 \\
\hline
\end{tabular}

There was a significant difference with respect to the source of information for self-medication among the two groups. Sources like seniors, magazines, advertisements, family and friends were more utilized by the medical students (Table 2).

Table 2: Source of information for self-medication.

\begin{tabular}{|llll|}
\hline Source & $\begin{array}{c}\text { Medical } \\
\text { n(\%) }\end{array}$ & $\begin{array}{c}\text { Paramedical } \\
\text { n (\%) }\end{array}$ & $\begin{array}{c}\text { 'p' } \\
\text { value }\end{array}$ \\
\hline Seniors & $38(28.1)$ & $15(13.4)$ & 0.005 \\
\hline Magazines & $43(31.9)$ & $20(17.9)$ & 0.012 \\
\hline Advertisements & $58(43)$ & $26(23.2)$ & 0.001 \\
\hline $\begin{array}{l}\text { Family and } \\
\text { friends }\end{array}$ & $104(77)$ & $70(62.5)$ & 0.013 \\
\hline Internet & $89(65.9)$ & $40(35.7)$ & 0.00 \\
\hline Pharmacist & $43(31.9)$ & $40(35.7)$ & 0.52 \\
\hline Health workers & $31(23)$ & $20(17.9)$ & 0.326 \\
\hline
\end{tabular}

The most common conditions for which self-medication was used were fever, cold and cough, headache, gastritis while the most common medications were analgesics, antipyretics, antacids and antibiotics (Figure 1, 2). Allergy, sleep, fatigue and GI upset were the most 
common side effects experienced by all the students (Figure 3).

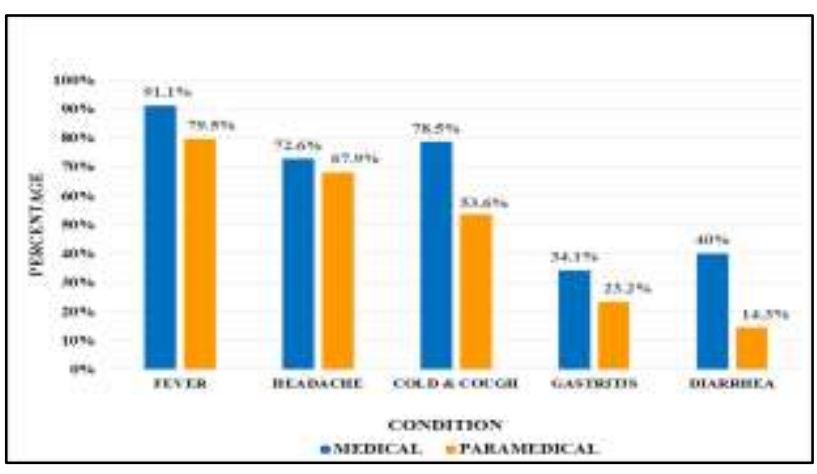

Figure 1: Common conditions for taking self-medication.

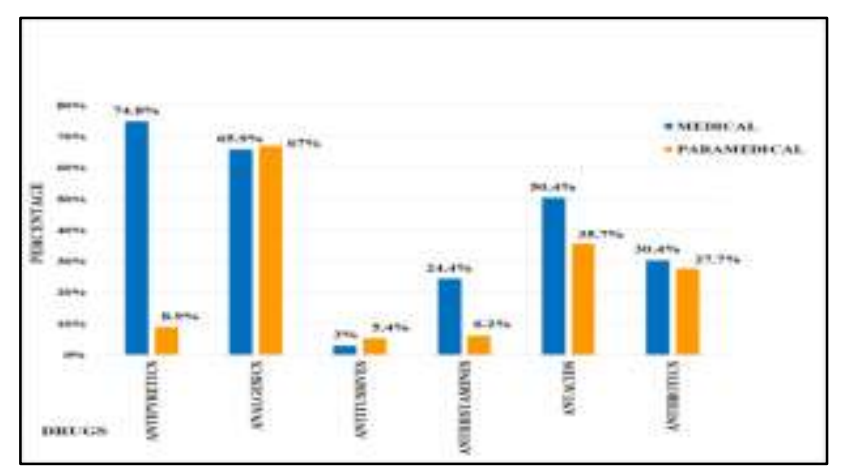

Figure 2: Commonly used drugs.

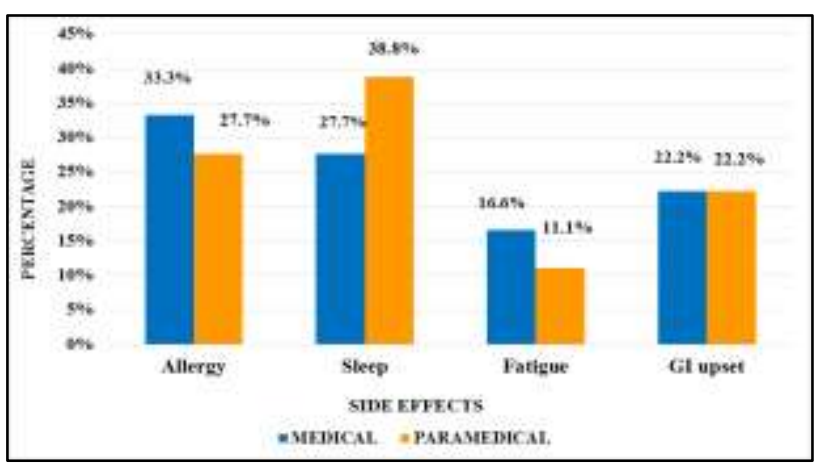

Figure 3: Common side effects experienced.

The reasons for taking self-medication were minor illnesses, saves time and money, avoid hassles from going to doctor, left over medicine at home. However, significant number of medical students took selfmedication because the drug resolved the illness previously for the students themselves or for family and friends (Table 3 ).

However, there was no significant statistical difference among the 2 groups of students regarding the disadvantages of self-medication. However, the common ones were: side effects, lack of knowledge, unaware about route and frequency of administration, drug interactions.
Table 3: Reasons for self-medication.

\begin{tabular}{|lccl|}
\hline Reason & $\begin{array}{c}\text { Medical } \\
\text { n(\%) }\end{array}$ & $\begin{array}{c}\text { Paramedical } \\
\text { n (\%) }\end{array}$ & $\begin{array}{l}\text { 'p' } \\
\text { value }\end{array}$ \\
\hline Minor illness & $112(83)$ & $86(76.8)$ & 0.22 \\
\hline Save time and money & $67(49.6)$ & $13(11.6)$ & 0.00 \\
\hline $\begin{array}{l}\text { Avoid going to } \\
\text { doctor }\end{array}$ & $54(40)$ & $18(16.1)$ & 0.00 \\
\hline $\begin{array}{l}\text { Resolved illness } \\
\text { previously }\end{array}$ & $69(51.1)$ & $35(31.2)$ & 0.002 \\
\hline $\begin{array}{l}\text { Resolved illness in } \\
\text { family and friends }\end{array}$ & $44(32.6)$ & $18(16.1)$ & 0.003 \\
\hline $\begin{array}{l}\text { Left over medicine at } \\
\text { home }\end{array}$ & $4(3)$ & $5(4.5)$ & 0.53 \\
\hline
\end{tabular}

\section{DISCUSSION}

William Osler once commented, "The desire to take medicine is perhaps the greatest feature which distinguishes man from animals." This desire plays a key role for the practice of self-medication which can be defined as utilization of drugs without the advice of a physician either for diagnosis, prescription or surveillance of treatment. $^{9}$

Various studies have reported the practice of selfmedication among medical as well as non-medical students. Hence, the present study was planned to compare among medical and paramedical students so as to bring about a change in the academic activity. In the present study, the prevalence of self-medication was $100 \%$ unlike other studies were the prevalence ranged from $57.1 \%$ to $92 \% .^{9-11}$ In a study conducted by Abay et. al $55.6 \%$ of students agree with the concept of selfmedication whereas in the present study, $47.3 \%$ of the students agree. ${ }^{12}$ Here, an imbalance was noticed with respect to the practice of self-medication and agreeing with the concept of self-medication. The reason may be lack of confidence, inappropriate awareness about the medicines, their benefits and hazards. In addition to minor illnesses and financial benefits which were the common reasons for students taking self-medication as observed in a study conducted in North West Ethiopia, the other common factors in our study were, the drug resolved the illness previously for the students themselves or for family and friends and also it avoids hassle going to doctor. $^{13}$

With respect to the most common conditions for taking self-medication and most commonly used drugs, $91.1 \%$ medical and $79.5 \%$ paramedical students took medicines for fever. But the use of antipyretics among the 2 groups was only $74.8 \%$ and $8.9 \%$. Likewise, $78.5 \%$ medical students and $53.6 \%$ paramedical students took selfmedication for cold and cough. But the use of antitussives among medical and paramedical students was $3 \%$ and $5.4 \%$ respectively and the use of antihistamines was $24.4 \%$ and $6.2 \%$ respectively. In comparison to antitussives and antihistamines, the use of antibiotics was 
more among the two groups of students. Use of antibiotics for a short duration of time or abrupt cessation without completion of course of therapy would expose the infecting bacteria to sub therapeutic levels of the drug leading to bacterial resistance. ${ }^{14}$ In a previous study conducted in Nepal, among medical and paramedical students, $60.3 \%$ of respondents used pharmacist as a source of information which is higher than that reported in our study (43\% medical and $40 \%$ paramedical). ${ }^{15}$

\section{CONCLUSION}

The present study shows a high prevalence of selfmedication among medical and paramedical students of the institution. The knowledge about self-medication was encouraging among the students of both the groups but the attitude and practice was imbalanced. Appropriate use of a drug for a particular condition was better among medical students than paramedical students and the attitude about reasons for self-medication was better among paramedical students than medical students. Hence, it is very important to raise the awareness about the pros and cons of self-medication in medical college students to improve their knowledge and attitudes towards practices of self-medication and eventually to increase the awareness in the society.

\section{ACKNOWLEDGEMENT}

We express our humble gratitude to the second year medical and paramedical students of K.S. Hegde Medical Academy, Mangaluru, Karnataka, India.

\section{Funding: No funding sources}

Conflict of interest: None declared

Ethical approval: The study was approved by the Institutional Ethics Committee

\section{REFERENCES}

1. Ali S, Sharma S, Ahmed T, Sharma R, Jaiswal M, Chaurasia R. Evaluation of self-medication amongst nursing students of bastar region: a questionnaire based study. International Journal of Pharmacological Research. 2015;5(6):145-49.

2. Bennadi D. Self-medication: a current challenge. J Basic Clin Pharma. 2014;5(1):19.

3. Kayalvizhi S, Sennapathi R. Evaluation of the perception, attitude and practice of self-medication among business students in 3 select cities, South India. International Journal of Enterprise and Innovation Management Studies (IJEIMS). 1(3):40-4.

4. Gutema GB, Gadisa DA, Kidanemariam ZA, Berhe DF, Berhe AH, Hadera MG, et al. Self-Medication practices among health sciences students: the case of
Mekelle University. Journal of Applied Pharmaceutical Science.2011;01(10):183-9.

5. Role of pharmacist in health care system. Available at http://apps.who.int/medicinedocs/en/d/Jh2995e/. Accessed 27 November 2015.

6. Keshari S, Kesarwani P, Mishra M. Prevalence and pattern of self-medication practices in rural area of Barabanki. Indian Journal of Clinical Practice. 2014;25(7):636-9.

7. Sontakke SD, Bajait CS, Pimpalkhute SA, Jaiswal KM, Jaiswal SR. Comparative study of evaluation of self-medication practices in first and third year medical students. Int $\mathrm{J}$ Biol Med Res. 2011;2(2):561-4.

8. WHO guidelines for the regulatory assessment of medicinal products for use in self-medication. 2000 Available www.who.int/medicines/library/qsm/whoedm-qsm2000- 1/who-edm-qsm-00_1.htm. Accessed 27 November 2015.

9. Sawhney V, Bhat M, Singh Z. A descriptive study of prevalence, pattern and attitude of self-medication among second professional medical students in a tertiary care center. Int J Basic Clin Pharmacol. 2015;4(3):542-6.

10. Badiger S, Kundapur R, Jain A, Kumar A, Pattanshetty S, Thakolkaran N, et al. Self-medication patterns among medical students in South India. Australas Med J. 2012;5(4):217-20.

11. Shivamurthy S, Manchukonda R, Gurappanavar D. Evaluation of analgesic self-medication pattern among under-graduate medical students of Adichunchanagiri Institute of Medical Sciences, BG Nagar, Karnataka : a cross-sectional questionnaire-b. IJBCP International Journal of Basic and Clinical Pharmacology. 2015;4(3):438-41.

12. Sm A, Amelo W. Assessment of self-medication practices among medical, pharmacy, and health science students in Gondar University, J Young Pharm. 2010;2(3):306-10.

13. Abula T, Worku A. Self-medication in three towns of North West Ethiopia. Ethiop J Health Dev. 2001;15:25-30.

14. Philip PT, Senan A, Reji S, Kumar TRA. Assessment of self-medication practices among undergraduate medical and paramedical students: a case of rural medical schools of Tamil Nadu, India. 2015;4(10):1587-604.

15. Poudel PP, Saha A. Knowledge, attitude and practice of self-medication among basic science undergraduate medical students in a medical school in Western Nepal. J Clin Diagn Res. 2015;9(12):17-22.

Cite this article as: Mapala $\mathrm{P}$, Holla R, Acharya S, Zachariah T, Aipanjiguly P. self-medication among medical and para medical students in a medical college, Mangaluru, Karnataka, India. Int J Basic Clin Pharmacol 2016;5:865-8. 